\title{
The path-dependent design of international organizations: Federalism in the World Health Organization
}

European Journal of International Relations 2015, Vol. 2I(I) 215-239

(C) The Author(s) 2014

Reprints and permissions: sagepub.co.uk/journalsPermissions.nav DOI: I0.1 I77/I354066 I I45300 I I ejt.sagepub.com @SAGE

\section{Tine Hanrieder}

Geschwister-Scholl-Institute for Political Science, LMU Munich, Germany

\begin{abstract}
The article puts forward a historical institutionalist account of how international organizations are 'designed.' I argue that deliberate institutional design is circumscribed by path-dependent power dynamics within international organizations. Power-driven path dependence is used to explain that organizations lock in and reinforce historical privileges of international organization subunits. Early winners in the international organization lock in their privileges with the support of member-state allies, and reap increasing returns from their positions over rounds of reform. They thereby amplify features of international organization design that reformers would otherwise change later on. The argument is illustrated with a historical case study of the World Health Organization's unique federal design, which grants the regional offices near autonomy from headquarter oversight. Vocal criticisms of the World Health Organization's regionalization and repeated centralization attempts notwithstanding, the powers of the regions have increased over time. The case study retraces the path-dependent struggles over the World Health Organization's federal design since its creation in the 1940s. While the literature on international organizations tends to reserve inertia and path dependence for constructivist analysis, this article offers a rationalist account of inertia in international institutions.
\end{abstract}

\section{Keywords}

Governance, historical sociology, institutions, intergovernmental organization, International Relations, regionalization

\footnotetext{
Corresponding author:

Tine Hanrieder, Geschwister-Scholl-Institute for Political Science, LMU Munich, Oettingenstr. 67, München, 80538, Germany.

Email: tine.hanrieder@gsi.uni-muenchen.de
} 


\section{Introduction}

Since its establishment in 1946, the World Health Organization (WHO) has lived through manifold changes. New political and technical demands, calls on its bureaucracy to 'change or die' (Chow, 2010; Smith, 1995), and competition from a plenitude of organizations now working in the field of global health (Hanrieder, 2014a) have challenged the United Nations (UN) health agency over the decades. The WHO has managed to survive in a dynamic environment by encompassing developing-country demands in the wake of decolonization, developing and taking up new policy schemes, and also by extending its authority, for example, in the domain of disease surveillance and outbreak response (see Chorev, 2012; Hanrieder, 2013; Lee, 2009; Zacher and Keefe, 2008). Yet, throughout all these changes, one of the most peculiar features of the WHO - its division into six quasi-autonomous regional organizations — seems to be inalterable. This structural resilience is puzzling insofar as regionalization is not only one of the most peculiar, but also one of the most challenged, features of the WHO.

The WHO's federal structure is extraordinary when compared to other international organizations (IOs). Its six regional bureaus are not merely implementing offices, but quasi-separate organizations. ${ }^{1}$ The regional committees - the WHO's regional memberstate forums - parallel the policymaking functions of the World Health Assembly (WHA). Moreover, the six regional offices are headed by independently elected Regional Directors and enjoy close to operative autonomy in administering the WHO's countrylevel activities (Beigbeder, 1997: 56-60). Hence, although the WHO's policies are officially determined by the WHA, and directed by the headquarters in Geneva, their implementation crucially depends upon the consent and collaboration of the regions, through which all information and resources have to pass (Jacobson, 1973: 201). While most operational agencies, such as the Food and Agriculture Organization of the United Nations (FAO) or the International Labour Organization (ILO), also dispose of regional and country offices, the level of autonomy granted to the WHO's regions is unique in the universe of UN organizations (Beigbeder, 1997: 52-69; FAO, 2007). ${ }^{2}$

One may suggest that this unique regionalization is the reflection of uniquely decentralized tasks that the WHO has to fulfill. Indeed, the WHO does engage in technical cooperation work next to its normative (i.e. standard-setting) activities. Few would question that the WHO needs to entertain a field presence to be able to provide technical advice to health ministries and respond to regional and local diversity regarding health systems and conditions. However, two related observations shed doubt on a functional explanation of the WHO's extreme regionalization. First, the design of the WHO's regional organizations has become the object of growing criticism — precisely because it is blamed for undermining the organization's field-level effectiveness. The power held by the regions has been described as pathological 'fragmentation' - a bureaucratic structure that creates internal friction and duplication, hinders policy implementation, and makes the organization unaccountable to its principals (Graham, 2013; see also Levine, 2006). For example, external evaluations by development agencies and by the UN managerial inspection unit admonished that the WHO regional offices absorbed scarce resources for technical cooperation instead of creating country-level impact, that resource allocation was not based on need but on politics, and that the regions were 
collaborating neither among each other nor with WHO headquarters (Daes and Daoudy, 1993; Danida, 1991). Furthermore, internal reports, such as the evaluation of the Roll Back Malaria partnership, made regionalization responsible for failure in one of the WHO's core domains of work: the development of policy standards (Roll Back Malaria and World Health Organization, 2002: 59). Hence, regionalization has come to be seen as undermining the WHO's 'faithfulness' (Graham, 2013), and, therefore, a cause for reform (Sridhar and Gostin, 2011).

Thus, second, the record of negative assessments of the WHO's regionalization has provoked repeated yet futile recentralization attempts over the organization's lifetime. As I will discuss in greater depth later, a range of influential member states and directorsgeneral (DGs) have tried to recast the WHO's federal structure so as to strengthen central oversight and coordination. None of these initiatives was successful. To the contrary, in a gradual but steady process of bureaucratic authority transfer, the regional organizations have gained greater discretion in terms of budgeting, staffing, and programming authority, thereby cementing their unique position (Beigbeder, 1997: 56-60).

How is it that the WHO's regionalization has been reinforced despite all allegations of dysfunction? How is it that the redesign attempts by powerful states and DGs have consistently failed? In this article, I will develop a path-dependence explanation of IO design to show how institutional power struggles interfere with the 'rational design of international institutions' (Koremenos et al., 2001a). Drawing on historical institutionalism (HI), I claim that the WHO's ongoing regionalization is a path-dependent outcome of the historical bargain struck during its founding moment (1946-1948). The initial settlement of the WHO constitution had a regionalist bias due to the strong position of the already-existing Pan American Sanitary Bureau (PASB). This granted the regional organizations a power advantage that was subsequently locked in through decision rules and the formation of member-state coalitions benefitting from, and thereby protecting, regionalization. It was further reinforced as the regional organizations reaped increasing returns from their power over rounds of reform. WHO DGs granted the regions additional authorities as they sought to secure organizational support for their policies. This pathway has proved impossible to reverse. Where deliberate attempts at countering regionalization were made, they were defeated, even if the initiators were powerful donor states such as the US. To date, regionalization represents as an absorbing state or attractor within the $\mathrm{WHO}$, meaning that regionalizing transformations succeed and stick, while centralizing transformations are consistently defeated (Pierson, 2004: 93-95).

The analysis of the WHO's self-reinforcing regionalization illustrates that in the process of IO design, historical causes stretch far into the present, constraining the impact of 'current conditions' and intentions on IO design. Apart from this general 'path-dependence' claim (Mahoney, 2000), the article contends that HI offers a means to bring power to the analysis of institutional design. HI helps to theorize how institutions empower and incentivize actors to protect their institutional privileges. The outcome of their struggles may be inefficient from a collective point of view - and thus not meet expectations of 'rational design' (Koremenos et al., 2001a). Yet, path-dependent IO outcomes can be rational from a distributional perspective, reflecting the actors' power positions in the institution. These positions, rather than intelligence, account for the time horizons of different actors. Hence, what I call here 'power-driven path dependence' (PDPD) is a means 
to explaining seeming pathologies in IOs in rationalist terms. The article thereby seeks to transcend the more or less explicit division of labor between rationalist and constructivist approaches to IO change in International Relations (IR) (see Nielson et al., 2006) whereby rational IO design and adaptation are the domain of rational choice (Koremenos et al., 2001a), while IO pathology and inertia are attributed to IO 'cultures' (Barnett and Finnemore, 2004; Weaver, 2008).

The article is divided into two main parts. The first part presents the theoretical logic of path-dependent IO design and discusses the methodology of identifying historical determination. The second part reconstructs the origins, lock-in, and reinforcement of the WHO's regionalization in three main steps. I first analyze the WHO's founding moment and ensuing lock-in of its regionalized structure. I then examine the WHO's first major reform under Halfdan Mahler (1973-1988) that reinforced regional powers, and finally turn to Gro Harlem Brundtland's (1998-2003) One WHO reform that failed to reverse regionalization. The conclusion reconsiders the argument and its relevance for institutional design theory.

\section{Path-dependent IO design}

$\mathrm{HI}$ is an established research tradition in comparative politics that is slowly also taking root in IR scholarship (Fioretos, 2011). Given that this tradition comprises different strands and theoretical building blocks, its analytical coherence and value-added are often disputed (e.g. Drezner, 2010). Therefore, this article does not draw on HI per se, but on an analytical core of this tradition and the contribution that it can make to rational institutionalism in IR. This is the focus on the institutionalization of power relationships. ${ }^{3}$

\section{History and increasing returns to institutional power in IOs}

In the rational institutionalist literature on IO design, the choice of institutional features is explained in functional terms. States choose those institutional features that best serve their collective, cooperative purposes - and they intentionally modify those features when they no longer serve collective purposes (Koremenos et al., 2001a). To this functionalist framework, power can be added as an exogenous condition for the supply of costly institutions (Keohane, 1984; Martin, 1992: 783-789), or for the choice of a particular equilibrium (Krasner, 1991). Yet, what is mostly missing from rational institutionalist analyses are conceptualizations of how institutions and power interact (Stone, 2009: 48-49; but see Gruber, 2000; see also Barnett and Duvall, 2005). Although power and distributional conflict are, in principle, compatible with a rationalist research agenda, they are often not integral to rational institutionalist analyses (Moe, 1990; see also Koremenos et al., 2001b: 1067-1069).

By contrast, power is central to historical institutionalist scholarship that is concerned precisely with the distributional dimension of formal institutions (Moe, 2005: 229). Historical institutionalists view institutions as structures that perpetuate the outcomes of historical struggles (Hall and Taylor, 1996: 941; Thelen, 2004: 31). Due to their powerladen nature, institutions are not reducible to the exogenous interest and power 
constellations among participating actors, but become themselves determinants of their future evolution. This approach to institutional change can be labeled 'power-driven path dependence.' It rests on distinct assumptions about institutional power, actor orientations, and institutional change.

First, PDPD emphasizes that formal institutions lock in political power. Institutions confer formal rights and veto opportunities on participating actors, and they provide them privileged access to organizational resources and information, as well as ties with supporters in the institution's environment. Thereby, historical winners can preserve initial advantages via institutionalization. The most prominent IR example for the institutionalization of political power is the UN Security Council, whose five permanent veto powers (P5) still consist of the post Second World War winning coalition. Since any change to this decision rule would hinge on their agreement, these veto positions are 'self-referencing' (Pierson, 2004: 145) and thus difficult to overturn. The Council's status quo bias illustrates that institutional power, especially a veto position, grants actors considerable influence over institutional decisions and the direction of institutional change. Even if the geopolitical constellation has markedly changed since the 1940s, the P5 have thus far protected their privileged status against rising powers' bids for permanent membership.

Yet, it is not only member states, but also bureaucratic units of IOs, who can preserve historical advantages. They can build coalitions with states who benefit disproportionately from their activities (Kleine, 2013), and who will protect these subunits even if a majority of states seeks to abandon them. For example, the quasi-autonomous thematic 'sectors' of the UN Educational, Scientific and Cultural Organization (UNESCO) have provoked opposition and criticism from many states seeking to simplify and harmonize the organization's work. Nevertheless, they have preserved their position until the present day (Roman-Morey and Zahran, 2011). The status quo bias of formal institutions can empower states and bureaucrats alike (see Strange, 1998).

Second, and relatedly, PDPD assumes that the actors cooperating in political institutions are sensitive to institutional power. They care about their 'economic' welfare gains from, as much as about their 'political' power within, these institutions (Knight, 1992; Moe, 2005). This assumption distinguishes PDPD from functionalist strands of rationalist cooperation theory such as the 'rational design' approach. In rational design theory, actors care primarily about institutional efficiency and collective goals (Koremenos et al., 2001a). The chance to create efficient institutions, therefore, hinges on the designers' far-sightedness and intellectual capability to choose the right design (but see Krasner, 1991: 336). Viewed from the angle of rational design theory, dysfunctional inertia is above all a problem of 'bounded rationality,' that is, the designers' inability to anticipate future gains from current investments in institutional reform (Jupille et al., 2013). Here, myopia, or even a motivational attachment to the past (Fioretos, 2011: 373-376), becomes the metatheoretical solution for explaining institutional stickiness (see Barnett and Finnemore, 2004).

By contrast, PDPD does not consider institutional stickiness to pose a challenge to rational choice per se. Instead of making inertia and inefficiency a metatheoretical problem, PDPD focuses on how institutional conditions shape actor strategies. Depending on their institutional position, actors can be protective of the status quo out of strategic 
considerations. They want to be able to control future outcomes and therefore defend institutional privileges even if this entails immediate losses or losses in collective efficiency. Hence, even designers who anticipate the welfare gains from efficiency-enhancing reforms will resist reforms that reduce their influence. A paradigmatic example of this conflict is the notorious debate about reducing the number of EU commissioners. Although the Lisbon Treaty foresaw a reduction in size upon enlargement, upon the accession of Croatia in July 2013, the EU's member states decided to prolong the 'one commissioner per country' rule until 2019. Regarding the size of the EU Commission, efficiency concerns are outweighed by member states' concern for institutional influence and their ability to veto downsizing attempts. ${ }^{4}$ Consequently, from the PDPD angle, the time horizons of political actors are not a matter of cognitive capacity, but of institutional position. Actors who can afford temporary losses are better placed to protect their longterm power-political interests than actors who depend upon immediate gains from cooperation. ${ }^{5}$

Third, PDPD assumes that institutions do not merely freeze past choices, but are determinants of their own development. Here, 'path-dependent' change is not the same as non-change. Nor is it a punctuated equilibrium view of institutional development, where change only occurs during major shocks, so-called 'critical junctures,' which are marked by radical historical openness (see Capoccia and Kelemen, 2007; Krasner, 1984). Path-dependent change means directed change: path-dependent institutional features are those that are locked in and thus costly to reverse, and that are reinforced as the institution evolves (see Mahoney, 2000; Page, 2006). This notion of path-dependent change is based, on the one hand, on the insight that political institutions are inherently dynamic. They do not persist by filling some political void, but must be constantly re-enacted in their changing environment. Institutional persistence is an ongoing collective achievement (Thelen, 1999; see also Barnes, 2001). IOs, too, have always been faced with changes in their environment: technical changes such as new communications software; economic changes such as funding shortages or currency fluctuations; political changes such as decolonization and the influx of new member states; or normative changes such as the rise of new policy demands. Such exogenous changes ${ }^{6}$ require active adaptations in order to legitimize the IO vis-a-vis its environment.

On the other hand, directed change means that not all institutional transformations are equally likely. The direction of institutional change is shaped by pre-existing power structures in which actors use their veto opportunities to block transformations that jeopardize their privileges. Well-positioned players can even seek to reap 'increasing returns' from their power and consolidate their positions (Mahoney and Thelen, 2010: 7). ${ }^{7}$ Their ability to do so will hinge on the reproduction requirements an institution faces over time, and thus is not fully decided ex ante (see Pierson, 1996). Yet, given the preceding considerations, we can conclude that increasing returns to power will in particular accrue to veto players with relatively long time horizons, that is, actors who have no immediate incentive to quit the status quo, but whose cooperation is needed when reformers strive to implement institutional or policy changes. Reformers, then, must mobilize these veto players, for example, by offering them institutional concessions in exchange for their collaboration. Reform opponents will, therefore, be strengthened over 'rounds of adaptation.' 
Such a dynamic has been observed in the context of federal systems such as the German Reich and the German Federal Republic, whose reproduction gave rise to highly centrifugal dynamics over time (Scharpf, 1988: 255):

And if the federal government insisted upon its objectives, it often had to buy support for national policies at the expense of permanent improvements of the institutional and financial position of the Länder. Thus, just as the emperors of the Holy Roman Empire were forced to expend their dynastic possessions and, finally, the imperial prerogatives, in order to maintain the loyalty of their vassal princes, so the German federal government has seen its share of total revenue reduced from 53 per cent in 1970 to 48 per cent in 1983.

The dynamic of cumulative subunit empowerment in federal systems shows that leaders need not always be the most powerful players in an institution. In fact, leaders are usually under stronger adaptation pressure than the subunits. This also holds for IOs. In fact, many heads of secretariat in IOs bid for election with concrete reform promises, and are held accountable for delivering on them. This puts them under pressure to make deals with veto players in the organization. As soon as IO subunits have the formal possibility to block reform decisions, or the informal possibility to block reform implementation, reformers need to create positive incentives so that the subunits buy into the reform. Over rounds of reform, subunits with early positional advantages can, therefore, grow more powerful. In aggregate, early institutional features will be reinforced though a pathdependent dynamic of IO change.

To empirically illustrate this theoretical argument, the second main part of the article will present a historical case study of the WHO's path-dependent regionalization. Before examining how path-dependent dynamics played out in the WHO's design and two major reforms, some reflections on the methodological status and internal validity of this investigation are in order.

\section{The methodology of studying path-dependent regionalization}

Claims of path-dependent IO change are claims of 'structural determination' (Pierson, 2004: 92-95). They refer to the aggregate direction of change rather than the timing of individual transformations. To examine the WHO's development from the PDPD perspective thus requires, first, that we adopt a processual approach in order to assess which transformations stuck with the organization over time. Mapped along the regionalizationcentralization dichotomy, the WHO's evolution displays a coherent regionalization process (see Figure 1). Throughout the WHO's history, regionalizing moves have been successful, while centralization attempts have consistently failed. This is a strong first indicator of directed, path-dependent change.

Second, to what extent the regionalizing transformations along this chain resulted from institutional constraints rather than choice needs to be gauged. Here, the challenge is that institutional effects are not as plain and manifest as (seeming) intentional choices. Institutions shape behaviors in subtle ways, by constraining actors' choices and removing certain options while making others more feasible (Bachrach and Baratz, 1962). Manifestly, however, institutional transformations are carried out by purposeful actors, 


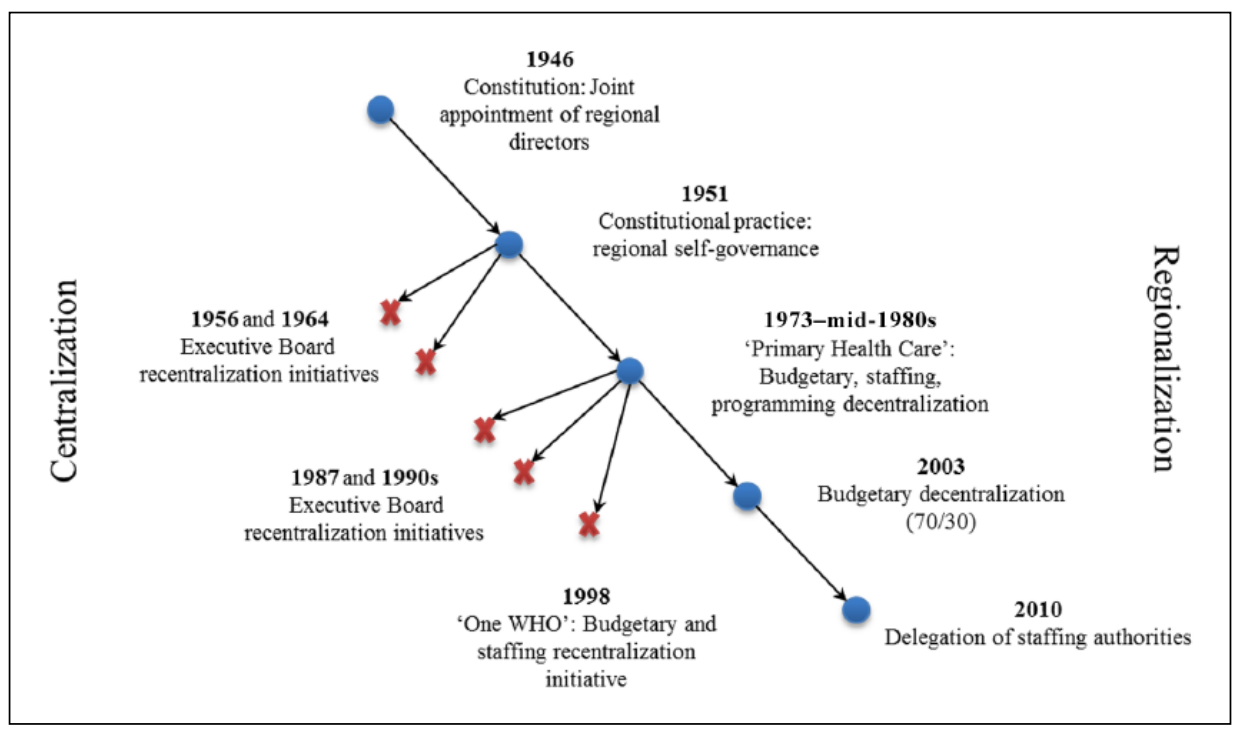

Figure I. The linear regionalization trend.

who, at least in the short run, have 'chosen' this pathway in the light of institutional incentives. The omnipresence of intentional actors, then, raises the counterfactual question of what we can reasonably call 'unintended' institutional developments (see Gruber, 2000; Wendt, 2001).

The following study, therefore, investigates historical design attempts during the WHO's three major design and reform episodes, that is, instances where deliberate choices directly confronted institutional constraints. These episodes are: the initial institution-building (design attempt) that lasted from 1946 until 1951; the 'Primary Health Care' (PHC) reform of DG Halfdan Mahler (reform attempt) of the 1970s and 1980s; and the One WHO reform of DG Gro Harlem Brundtland (reform attempt) of the late 1990s. In each sub-case, I distinguish between initial design/reform goals, institutional outcomes, and later attempts at reversing the outcome. This temporal separation of goals and outcomes allows for context-sensitive counterfactuals about the institutional outcomes that would have been attained in the absence of path dependence. Here, one counterfactual indicator of PDPD results from comparing reform goals with institutional outcomes. Strong evidence for the PDPD claim will consist in such regionalizing transformations that were unintended by the design or reform coalition. A second counterfactual check of the PDPD claim focuses on the robustness or 'lock-in' of regionalization. For this purpose, I retrace the fate of recentralization attempts launched by WHO leaders and member states. Strong evidence for the robustness of the regionalization pathway will consist in recentralization attempts that are promoted by powerful member states but are blocked in the governing bodies.

The study's focus on explicit design and reform uses a demanding benchmark for path dependence. It only examines instances where path dependence is explicitly challenged 
by intentional designers. In fact, path dependence should also be at play in myriad nonevents that are left out by this design. IO designers and reformers are usually aware of and anticipate institutional constraints and may, therefore, refrain from certain options from the outset. An analysis centered on explicit struggles omits such anticipation effects that could further strengthen the PDPD claim (cf. Fearon, 1998).

\section{The WHO's regionalization pathway}

This section analyzes the WHO's regionalization pathway with a focus on its three major 'design' episodes: its founding moment (1946-1952); Halfdan Mahler's (1973-1988) PHC reform; and Gro Harlem Brundtland's (1998-2003) One WHO reform. It is mostly based on document analysis, ${ }^{8}$ complemented with elite interviews with former and current professional WHO staff members that are used as background information.

The historical analysis yields that institutional power already affected the WHO's initial design. The WHO was not created on a clean slate, but incorporated the legacies of several health organizations that had coexisted up until the interwar period, most importantly, the League of Nations Health Organization (LNHO), the Paris-based Office International d'Hygiène Public (OIHP), and several regional health bureaus, including the PASB (see Howard-Jones, 1978). Institutional legacies constrained the WHO's founders due, in particular, to the power vested in the PASB, which contributed to an unexpectedly regionalized structure. The PHC reform of the 1970s and 1980s reinforced this outcome as the regions were further empowered in the course of the reform. While (unsuccessful) recentralization attempts had already followed these two design episodes, the most concerted effort at curbing the regions' autonomy was made with the One WHO reform at the turn of the millennium. The failure of this attempt testifies to the lock-in of regional powers in the WHO. Each within-case study will be presented in the three-step heuristic outlined earlier: (a) design/reform goal; (b) design/reform implementation; and (c) attacks on the design/reform outcome.

\section{Region-building beyond the constitution: The PASB legacy}

The work on the WHO's design began in the aftermath of the 1945 San Francisco Conference on International Organization, whose participants had agreed to create a single health agency for the UN. Four countries - the UK, the US, France, and Yugoslavia - prepared constitutional drafts for the new organization, which were discussed at the so-called Technical Preparatory Committee (TPC) that gathered in Paris from 18 March to 5 April 1946. All these proposals foresaw some regional layer to be part of the WHO's design, yet they diverged sharply with regard to the extent of regional autonomies: while the UK and France held that regional offices should only provide epidemiological intelligence and advice on regional matters to the WHO headquarters, the Yugoslavian approach was less decided on this issue, and the US promoted a 'dual' solution whereby all regional offices should be firmly integrated with the WHO - apart from the bureau for the pan-American region (WHO, 1947a: 42-61).

Since 1902, the PASB had acted as the health agency of all American states except Canada, Newfoundland, and the British West Indies (Howard-Jones, 1981). ${ }^{9}$ The PASB's 
institutional power mainly rested on its nesting within the wider system of pan-American institutions and the allegiance of its Latin American supporting coalition. The PASB's integration, therefore, became the most controversial issue in the negotiations over the WHO's constitution. What is more, this conflict could not be settled with the formal constitutional compromise, but only after years of piecemeal institution-building which resulted in a de facto regionalization that far exceeded constitutional provisions.

Constitutional design. While the TPC members agreed rather quickly on most features of the WHO, the conflict over the WHO's regional design was only settled at the International Health Conference (IHC). The IHC struck a delicate compromise between adherents of a rather centralized WHO - among them, the UK, France, Norway, and the Soviet Union (Farley, 2008: 23-24; WHO, 1947a: 28-29, 42-45) - and proponents of strong regional offices, mostly members of the PASB. ${ }^{10}$ Notably, the US was rather hesitant in supporting the PASB's bid for continued autonomy (Farley, 2008: 23-24). Yet, given that PASB members made up 20 out of 51 delegations to the IHC, the defenders of the PASB could form a concerted bloc that effectively vetoed all attempts at dissolving the PASB into the WHO (Farley, 2008: 23-24). The WHO's founders, therefore, agreed on a compromise for the WHO constitution (Art. 54), which states that the PASB should 'in due course be integrated with the Organization. This integration shall be effected as soon as practicable through common action based on mutual consent of the competent authorities expressed through the organizations concerned.'

While this formula postponed the settlement of the PASB's status within the WHO, the IHC's decision regarding newly created regional offices aside from the PASB was more determinate. The WHO constitution (Art. 45) rules that the regional organizations must be 'integral parts' of the organization. This dual solution had first been proposed by the US representatives, who argued that apart from an 'autonomous' PASB, the WHO should be composed of '[d] ependent regional offices' (WHO, 1947a: 67-68). Therefore, the constitution further specifies that the Regional Directors shall be appointed by the Executive Board, 'in agreement' with the regional committee (Art. 52). A legal opinion published at the time assumed that the regional say would be used to block unwelcome candidates suggested by the Executive Board: 'Under this formula the initiative in nominating a Regional Director will presumably be taken by the Board, but the Regional Committee may force the Board to submit an alternative name (or names) if it objects to the original nomination' (Sharp, 1947: 518).

In sum, the WHO's constitutional design foresaw a transition period for the PASB but full integration for all other regional organizations, whose secretariats should be centrally controlled. Evidently, this compromise can itself be labeled path-dependent given that it paid attention to pre-existing institutional commitments. The PASB's institutional power manifested itself in its ability to coordinate and organize the Latin American bloc during the WHO's foundational conference and thus to prevent the WHO from immediately dissolving the PASB. Still, in the following, we will apply the stricter counterfactual probe for PDPD and use the 1946 constitution as the benchmark for design. Even assessed against this benchmark, the PASB's path-dependent institutional power was stronger than constitutional provisions and triggered an unanticipated regionalizing move throughout the WHO. 
Design implementation. Having effectively vetoed its immediate integration with the WHO, the PASB could further capitalize on its institutional head start in the wake of the WHO's founding conference. In fact, the ensuing institution-building process was marked by a temporal lag that was much longer than expected by the WHO's founders. While the drafters of the constitution had assumed that the required 26 ratifications would be gathered within months, the ratification process took nearly two years until April 1948 - an effect, not least, of the onset of Cold War tensions that put an end to the postwar internationalist moment (Farley, 2008: 48; Goodman, 1971: 167). The PASB contributed to this time lag and advised its members to withhold their ratification until a final agreement with the WHO was struck. In the meantime, the PASB overhauled its constitution so that in 1947, it became part of the newly established Pan American Sanitary Organization (PASO) (Calderwood, 1963: 23-24). In addition, the PASB's new Director Fred Soper launched a fund-raising campaign in order to make the PASB too big to absorb for the WHO (Soper, 1977: 322).

The WHO, by contrast, could only install a small Interim Commission until the organization became fully operational. This Commission was entrusted with negotiating an agreement with the PASB that determined the conditions of its integration. Due to their weak position vis-a-vis an invigorated PASB, the WHO negotiators grudgingly accepted an agreement that cemented the PASB's autonomy within the WHO. The agreement specifies that PASO's organs should serve as the WHO's regional committee and regional office for the Americas, but, at the same time, keep its independence. PASO, henceforth, wore two different hats, as 'in deference to tradition, both organizations shall retain their respective names' (WHO, 1949: 382): American Regional Office (AMRO) inside the WHO and PASO in the Americas. The WHO leaders made it clear that this compromise violated the constitution in their eyes and that they were looking for ways to proceed to 'full' integration (Farley, 2008: 100-101; WHO, 1948b: 27; 1949: 383). Nevertheless, the agreement has remained in force ever since.

Hence, the PASB's institutional power effectively trumped the WHO's constitutional design. This outcome was path-dependent because without a pre-existing PASB around which Latin American states could rally, the WHO's design would most probably not have provided for an autonomous American office. Importantly, this outcome can not be reduced to the usual suspect in IO design explanations: US power. In fact, US representatives to the WHO's founding conferences were at best ambivalent with regard to preserving a strong pan-American branch. Turning from pan-Americanism to internationalism in the wake of the Second World War (Hull, 1948: 1640-1647), the US was also shifting its health support from the PASB to bilateral channels such as the newly created Institute of Inter-American Affairs (Soper, 1977: 313-314). Therefore, the US delegates to the IHC were instructed to 'assure the supremacy of [the WHO] in all matters of world-wide concern' (quoted in Staples, 2006: 135). Furthermore, during the negotiation of the WHO-PASB agreement, the US pressured PASB member states to sign the WHO constitution without reservations (WHO, 1947b: 17). Against this backdrop, it is implausible that in the absence of a pre-existing PASB, the US would have supported strong regionalization in the WHO. This is also shown in US advocacy of strong integration for all newly established WHO regional organizations - which would turn out to be futile, however. 
The region-building process that started in 1948 further exceeded the constitutional design in the direction of regionalization (see Figure 1). In spite of their constitutional role as subordinate units, the five new regional organizations emulated this precedent. Still in accordance with the constitution (Art. 44), the new regional organizations were created in two steps. First, the first WHA in 1948 defined the geographical areas for future regional organizations. ${ }^{11}$ Subsequently, a majority of member states within the respective areas decided to inaugurate a regional organization. By 1952, the necessary majorities were gathered in all WHO regions. Yet, as the regional offices were established, they deviated from the constitutional procedure with regard to the appointment of their Regional Directors. Imitating the pan-American example, they did not consult with the Executive Board, but simply appointed their Regional Directors at the regional level. The regional committees then notified the WHO headquarters of their choice, which the Executive Board duly confirmed. This practice of regional self-governance accorded a very strong position to the Regional Directors. It provoked criticism in the secretariat and among member states for violating the WHO constitution (Ascher, 1952; Levy, 1982), yet it soon turned out to be resistant to recentralization attempts.

Lock-in. The WHO's early regionalization persisted by creating its group of winners, namely, states in need of basic assistance. Particularly for recipient states, the regional offices became the first port of call because the Regional Directors assumed responsibility for preparing the regional budgets (WHO, 1953: 157-184). Recipient states promptly used this vehicle to lobby for a budgetary scale-up: in 1950, responding to pressure from the regional offices, regional allocations were increased by $20 \%$ — an increase that was entirely dedicated to meeting country demands (Ascher, 1952: 38-39). The regional organizations thereby established themselves as distributional vehicles for countries seeking assistance from the WHO.

Accordingly, the winners of regionalization fended off a series of recentralization attempts that were made since the mid-1950s. These early tests for the 'robustness' of regional self-governance consisted of recentralization initiatives that were led by New Zealand in 1956 (WHO, 1956: 143-144), by Australia in 1958 (WHO, 1959a: 322-323; 1959b), and by Ireland in 1964 (WHO, 1964). All these motions aimed at strengthening centralized authority over Regional Director appointments so as to give effect to the constitutional provisions. In particular, the proposals included measures such as requiring lists of several candidates for the post of Regional Director to be submitted to the global organs of the WHO, and the rule that the final selection be left to the Executive Board and DG. These proposals were debated at the regional committees, where they were mostly rejected (WHO, 1958a: 23). At the Executive Board, they provoked lengthy debates, and despite several watered-down proposals resulted in deadlock. In the end, however, no decision could be reached apart from the formula that 'this important matter should be kept under study' (WHO, 1958b: 40; 1959a: 342-343). Regionalization thus resisted a first generation of attacks.

In sum, the history of the WHO's creation testifies to the importance of path dependence even during an IO's founding moment. The gap between the WHO's constitutional design and its actual system of regional self-governance demonstrates the impact that the PASB had on its federal design. The unsuccessful centralization attempts of the 1950s 
and 1960s testify to the robustness of the regionalization pathway. It must be cautioned, though, that the initiators of these early recentralization attempts were not the most powerful WHO member states, so the rejection of their proposals is not a very strong indicator of robust regionalization. A stronger challenge would follow in the aftermath of the WHO's first major reform.

\section{PHC and its secondary effects}

The WHO's first major reform process was initiated by Halfdan Mahler, who took office as DG in 1973. Mahler's WHO became a leading protagonist of the PHC movement. The PHC agenda was endorsed by the 134 states attending the 1978 International Conference on Primary Health Care in Alma Ata, Kazakhstan and became official WHO policy through a series of WHA resolutions (Litsios, 2002). Yet, the reform mainly produced secondary (institutional) instead of primary (policy) effects on the WHO: its implementation through the so-called 'Health for all by the year 2000' (HFA) reform strengthened the regional offices to the point of operational near-autonomy, but failed to alter health policies in the developing world. In the following, I will reconstruct the path-dependent constraints that led Mahler to further regionalize the WHO and the subsequent, yet futile, challenges brought against regional autonomy.

Reform agenda. PHC was introduced as a reaction to the health development crisis following decolonization. At the time, the colonial system of providing hospital-based care turned out as ill-equipped to improve health conditions in the developing world, and the movement for a New International Economic Order made development a priority also of the WHO. PHC was developed as a bottom-up and community-centered strategy to improve basic health systems (Cueto, 2004; Litsios, 2002). It should rely on a broad and intersectoral agenda for the transformation of health systems, encompassing prevention, education, the reliance on simply trained health workers, and agricultural development as means to improve health in developing countries (Newell, 1975). Resources should be shifted from expensive hospitals and medical schools toward intersectoral planning for national health systems. The implementation of PHC thus relied on country-level PHC strategies, an approach called country health planning (Litsios, 2002; WHO, 1976: 2).

Reform implementation. To make PHC work, Mahler proposed that scarce national resources needed to be allocated through rational systemic planning for each and any individual country, which would be aided by new computerized technologies developed at the WHO headquarters (Litsios, 2002: 717). Yet, to reach out to the country level, the PHC reform team had to work through the pre-established system of regionalization in the WHO. As we have seen in the earlier section, the regional offices had positioned themselves as the main addressees for budgetary demands by the countries. Their pathdependent institutional power was acknowledged by Mahler, who repeatedly stated (as bequeathed by D.A. Henderson) 'that WHO is, in fact, an Association of Regional Offices, not a World Health Organization' (Henderson, 2009: 85, emphasis in original). Mahler also observed that 'Member States are increasingly identifying themselves with their regions and this has been accompanied by an intensification of work in the regional 
committees in recent years' (WHO, 1979: 15, emphasis in original). The regional offices' strong ties with regional member states made them reluctant to rearrange their budgeting practices in line with headquarter-imposed policies such as PHC, as they instead prioritized the permanent and urgent procurement gaps that their budgets were designed to fill (Litsios, 2002: 720, 730).

Faced with resistance in the regional offices, and the factual veto position that the Regional Directors had thanks to their independent electoral base, Mahler relied on a mix of persuasion and positive incentives to rally for PHC. To persuade the regional organizations that they implement the PHC agenda, Mahler gave regular speeches at the regional committees, where he rallied for the HFA reform (e.g. Mahler, 1980, 1981, 1983a, 1984). In addition, over the 1970s, the DG engaged in a substantive delegation of administrative authorities to the regional layer. With regard to budgeting, he entitled the Regional Directors to freely allocate their regional share without centralized oversight and granted them full discretion over the allocation of WHO fellowships. With regard to staffing, the Regional Directors were delegated near-exclusive authority over regional staff except the highest professional category (D1) over the 1970s (Beigbeder, 1997: 57). Hence, through the HFA reform, the regions became self-reliant in operational terms (Mahler, 1975).

Mahler openly recognized the long-term risks of further regionalization and the concomitant loss in centralized authority that this involved: 'Their responsibilities will have to be increased, however risky this may appear at first sight' (Mahler, 1975: 44). He may well have anticipated that regional empowerment was hardly rescindable in the context of regional self-governance (see also Henderson, 2009: 85). This did not prevent him from expressing regret when it became clear over the 1980s that the regional offices did little to implement PHC measures. Only a few countries adopted elements of the reform such as country health planning (WHO, 2008: 44) or other PHC-related measures (Mahler, 1983b; WHO, 1980: 6; 1984: xvi). Evaluations of the WHO's technical cooperation activities exposed 'widespread, inadequate programme management beneath the veneer of administrative and financial correctness' (WHO, 1986: xxii; see also WHO, 1987b: 7). The DG formulated this accusation most bluntly in his address to the 1987 WHA. Assuming responsibility for having regionalized authority in the WHO to the 'absolute limits of the Constitution' (WHO, 1987c: 4), he expressed regret for the unintended outcomes of this move:

What I do regret is that it [regionalization] may be leading WHO to consist of six separate regional organizations and one separate headquarters organization. What I do regret is the increasing tendency to appoint staff in countries and in regional offices in their great majority from within the region. That to my mind contradicts the very spirit of the Constitution. What I do regret is that decentralization, rather than being accepted by each and every Member State as delegation to them of responsibility for the work of WHO and accountability to the Organization as a whole for the use of its collective resources, rather than that it is all too often being regarded as a blank cheque for pocket money. (WHO, 1987c: 5, emphases in original)

As it turned out, the Regional Directors did not comply with the WHO policy that they should only respond favorably to country requests that conformed to WHO programs (WHO, 2011a: 24). Mahler's public criticism of the regions was not only seconded by a 
range of external evaluations by development agencies (Daes and Daoudy, 1993; Danida, 1991) and articles in public health journals (Godlee, 1994; Peabody, 1995). It also provoked a series of recentralization attempts, this time initiated by powerful WHO members.

Lock-in. The new managerial authorities granted to the regional offices reinforced member-state allegiances and thus vested interests in regionalization. Executive Board members from developing countries, usually health ministry officials, often relied on the Regional Directors for employment beyond their service at the Executive Board (Godlee, 1994: 1567; 1995: 584). These relationships further strengthened regional allegiances, which, for many countries, became far more important than the work with and through the central governing bodies (Siddiqi, 1995: 77-82).

In the face of such positive feedback to deep regionalization, a renewed attempt to curb regional powers stood little chance of success, even though it was initiated by a US-led coalition. Together with the representative of Guyana, the US member of the Executive Board proposed to recentralize the WHO and strengthen the DG. Again, the proposal was made that Regional Directors be appointed upon suggestion by the DG and that centralized administrative control be reinforced (WHO, 1987a: 6). With the US being the greatest net contributor to the WHO's budget, this recentralization attempt was a stronger challenge for the robustness of regionalization than the initiatives of the $1950 \mathrm{~s}$ and 1960s. Yet, with many Executive Board members strictly opposing any infringement on regional self-governance, the Executive Board did not reach an agreement on the initiative (WHO, 1987a: 6-11). The Regional Directors' independent legitimation base was left untouched.

To sum up, the PHC reform illustrates how organizational veto players can reap increasing returns from their power positions in the process of IO reform. The regional organizations were empowered in order to mobilize their support for $\mathrm{PHC}$ - an attempt that failed as they did not implement the PHC agenda. Still, at the structural level, the reform had lasting effects, leaving the regional offices practically autonomous in operational terms. This path-dependent reform outcome turned out to be irreversible, as critics of regionalization tried in vain to curb regional powers in the aftermath of the $\mathrm{PHC}$ reform. The WHO's next major reform, called 'One WHO,' would again testify to the robustness of the regionalization pathway.

\section{Brundtland's One WHO hits regional resistance}

When Gro Harlem Brundtland, former Norwegian prime minister and head of the World Commission on Environment and Development (the 'Brundtland Commission'), was elected WHO DG in 1998, the expectation was that she would fundamentally restructure the organization. Under her predecessor, Hiroshi Nakajima, the WHO had lost much legitimacy and was accused of mismanagement, fragmentation, and lack of vision (Hanrieder, 2013). In contrast to Nakajima, who was mostly supported by developing countries, Brundtland was supported by the WHO's donor states, and enjoyed direct access to heads of government due to her former career (Andresen, 2002). The new DG sought to re-engineer the WHO with a managerial approach to international health and 
organization that was based on economic efficiency criteria and new public management techniques. Her short term in office yielded widely visible results such as new highprofile health partnerships (e.g. Stop Tuberculosis), a new international health treaty (the Framework Convention on Tobacco Control), an empowerment of the WHO in the domain of disease surveillance and control (Hanrieder, 2014a), and a general rise of health to the fora of high politics (Andresen, 2002). In the following, however, I will focus on Brundtland's structural reform goals for the WHO, especially her bid to integrate the regions into 'One WHO.'

Reform agenda. While policy failure had been the main concern of the WHO's reformers in the 1970s, by the end of the millennium, organizational problems had moved to the center of attention. Upon her nomination by the Executive Board in January 1998, the future DG installed a five-person 'transition team' to prepare her takeover six months later in mid-July. The team screened the WHO's policies and structure and developed proposals for an encompassing reform (Lerer and Matzopuolos, 2001). Central to this reform was the vision of 'One WHO' being capable of strategizing and engaging in radical change. The reform should cure the multifaceted fragmentation that the transition team had diagnosed: fragmentation into myriad programs and differently funded activities, and fragmentation between headquarters and the regions:

People spoke of more than $50 \mathrm{WHOs}$ - meaning the more than 50 individual programmes at Headquarters. They spoke of 7 WHOs, meaning Geneva and the six Regional Offices. They spoke about 2 WHOs, meaning the one financed by the regular budget and the one financed by extrabudgetary contributions. (Brundtland, 1999)

To infuse the WHO with entrepreneurship, a rapid turnover of staff was set into motion. Within three months until November 1998, the headquarters were completely restructured. Nearly all top staff were replaced with new appointees - many of them recruited from the transition team (Lerer and Matzopoulos, 2001: 430) — and 750 (out of about 1200) headquarter staff were rotated to new assignments, including a massive physical reshuffling between offices (Lerer and Matzopoulos, 2001: 429). Furthermore, to centralize organizational structures and foster corporate agency, the WHO's more than 50 headquarter programs were grouped into nine thematic 'clusters,' whose directors were directly accountable to the DG. The directors should directly work with their counterparts in the regional offices, who should henceforth develop program budgets in collaboration with WHO headquarters (Brundtland, 1998; WHO, 1999: xix). The 'One budget for One WHO' procedure was thus to replace the practice of regional budgeting that had been established in the 1950s and that had withstood the PHC reform (see earlier). Brundtland also sought to reassert headquarter control over regional staffing through the so-called 'country-focus initiative.' Country-level appointments in this program and the 'country cooperation strategies' based on it were made the responsibility of headquarters rather than the regional offices (Andresen, 2002: 18).

Reform implementation. If the integration of regional activities was, indeed, the 'big test' for the One WHO reform (Robbins, 1999: 36; see also Godlee, 1998), the reform has not 
passed its test. Resenting headquarter intrusion into their programming activities, the regional offices hardly collaborated in the clusters' budgeting procedure (Joint Inspection Unit, 2001: 17). In some regions, such as the African office, regional budgets remained practically unaffected by the corporate program budget (Yamey, 2002b: 1171). Given the lack of headquarter-regional communication also with respect to program implementation, the internal evaluation of the Roll Back Malaria program concluded, therefore, that one could hardly speak of 'One' WHO, despite the ambitious reform (Roll Back Malaria and World Health Organization, 2002: 59). When, to the surprise of her staff, Brundtland announced in 2002 that she would not seek re-election after only one term in office, it was speculated that the 'difficulty in making any real change to WHO's troubled regional structure' (Yamey, 2002a: 1111) had played a part in this decision.

Aftermath of One WHO. To date, Brundtland has been the last reformer to challenge the WHO's regionalization pathway. While the WHO's federal 'DNA' (Levine, 2006) continues to be the target of criticism (Levine, 2006; Posta and Zahran, 2012; Sridhar and Gostin, 2011; but see Horton, 2013), regional authorities are firmly entrenched. Indeed, after Brundtland's futile attempts to curb regional budgeting and staffing authorities, the WHO has again moved in the regionalizing direction (see Figure 1): Brundtland's successor, Jong-Wook Lee (2003-2006), introduced the '70\%-30\% principle,' which should ensure that regional and country-level expenses amount to about $67 \%$ to $70 \%$ (Yamey and Abbasi, 2003: 1252). ${ }^{12}$ In 2010, DG Margaret Chan delegated new staffing authorities to the Regional Directors, who can now also appoint staff in the highest professional category. ${ }^{13}$ This delegation was not widely publicized, so its underlying motivation can only be speculated about. It underlines, however, that the direction of change in the WHO's federal system is consistently toward further regional autonomy.

In sum, the One WHO reform may not have yielded increasing returns to the region's powers, yet it also failed at curbing regional authorities. Brundtland came to the WHO as an outsider, and thus was less prone to anticipate path-dependent constraints than another internally recruited leader. The deliberate challenge to regionalization posed by this high-profile politician thus provided an empirical challenge to the regionalization pathway that again underlined its robustness. Evidently, and as needs to be clarified here, the WHO's regionalization pathway has proven robust in the face of historical challenges, but it is not completely determined or even irreversible. Its regionalization has not been put to the 'ultimate test' of a major power coalition threatening all-out exit in pressing for reform. Thus, like all path-dependent processes, the WHO's regionalization has proven relatively irreversible: prior institutional choices made path reversal prohibitively costly for reformers, who opted for more gradual and endogenous reform strategies (see Pierson, 2004: 20-21). ${ }^{14}$ Path dependence has thus filtered, not eliminated, the impact of exogenous power on the WHO's institutional trajectory.

\section{Conclusion}

This article has used historical institutionalist concepts to reinvigorate the study of power in IO design. While the proponents of the rational design project have argued that power, defined in 'realist' terms as interstate asymmetries, fared poorly in explaining IO design 
outcomes (Koremenos et al., 2001b: 1967-1968), I have focused on endogenous, institutional sources of power. Path dependence was invoked to claim that institutions create formal and informal veto positions for the participating actors and thereby become sites of distributional struggle. Because political actors are sensitive to institutional power, they are protective of their veto opportunities, and thereby constrain the process of IO adaptation. Hence, the PDPD perspective offers a rationalist account of IO inertia, a phenomenon that is mostly referred to in constructivist (Barnett and Finnemore, 2004; Weaver, 2008) or bounded rationality (Jupille et al., 2013) explanations. HI helps to transcend this implicit division of labor in analyzing how institutions shape the strategies of the participating actors, as well as their time horizons, and thereby give rise to pathdependent processes of IO change.

The case study of the WHO's regionalization has illustrated these claims and demonstrated that even during the founding moments of IOs, pre-existing institutions can constrain design choices. The veto power vested in the WHO's regional offices has fuelled a process of directional change where transformations in the direction of further regionalization have consistently succeeded. By contrast, all recentralization attempts, even those initiated by the WHO's main donor state, have been unsuccessful. This trajectory illustrates that institutional power in IOs is not reducible to material statecraft, and points out the limits of deliberate $\mathrm{IO}$ reform.

Evidently, the WHO is an extreme case of regional decentralization in the universe of contemporary IOs. Indeed, path-dependent outcomes such as the WHO's federalism are, by definition, unique. Nevertheless, the mechanism of centrifugal reproduction observed in the WHO case can be observed in other IO contexts, too. For example, the UNESCO's thematic 'sectors' have held a historically strong position that yielded increasing returns over rounds of institutional reform: in the UNESCO context, decisions to decentralize activities to the regional or country level have been administered by 'parent' sectors, which thereby extended their control to regional and local branch offices. Although the resulting fragmentation has often been attacked as inefficient and dysfunctional, it seems to be as irreversible as the WHO's regionalization (RomanMorey and Zahran, 2011).

Cases like this suggest that IO research could gain a lot from studying the institutional mechanisms through which IOs are reproduced over time. How do coalitions form around certain institutions and parts thereof (Kleine, 2013), and how do these redistribute power among states and different units of IOs? Furthermore, how do domestic bureaucracies and trans-governmental networks contribute to locking in IO outcomes (Strange, 1998)? Finally, inter-institutional relations are likely to affect institutional trajectories. In a densely institutionalized global polity, the interaction of different institutional pathways, their mutual reinforcement or undermining, and their gradual replacement via differential growth rates are phenomena that invite a genuinely historical approach to the problem of IO design.

\section{Acknowledgements}

For constructive comments on earlier versions of this article, my special thanks go to Dirk De Bièvre, Andreas Dür, Stephanie Hofmann, Michel Horelt, Johannes Juede, Christian KreuderSonnen, Andreas Kruck, Berthold Rittberger, Duncan Snidal, Teresa Squatrito, Jonas Tallberg, 
Alexander Thompson, Bernhard Zangl, and the two anonymous reviewers of the European Journal of International Relations.

\section{Funding}

This research was supported by research grants from the Bremen International Graduate School of Social Sciences, the German Academic Exchange Service and Mentoring@LMUexcellent.

\section{Notes}

1. The WHO entertains regional organizations in six geographical areas: the Eastern Mediterranean Region, the Western Pacific Region, the Southeast Asia Region, the European Region, the African Region, and the American Region. Notably, the dividing lines between these regions are partially based on geographic and epidemiological criteria, but partially 'high politics' cleavages. For example, Israel moved from the Eastern Mediterranean to the European Region in 1985 to overcome political deadlock, and India and Pakistan joined different regions: the South-East Asia and Eastern Mediterranean, respectively (Siddiqi, 1995: 73-161).

2. In the UN, only the International Telecommunication Union (ITU) has elective managerial positions besides the director-general (DG) (Daes and Daoudy, 1993: 24).

3. For an alternative, sociological interpretation of HI in IR, see Dannreuther (2011).

4. See: http://euobserver.com/tickers/120206 (accessed 23 June 2013).

5. See the argument about one-shot versus repeat players in the judicial politics literature (Galanter, 1974; see also Alter, 1998: 131-132).

6. Evidently, many 'exogenous' changes are not causally independent from the activities of IOs, for instance, when an IO itself promotes a new policy paradigm. Nevertheless, the distinction between external challenges and institutional adaptation is analytically productive to capture the interplay between new demands and established institutions.

7. Note that 'increasing returns to power' (Mahoney and Thelen, 2010: 7) follow a distributional rationale and refer to the gradual empowerment of actors. This is to be distinguished from the collective 'increasing returns' that are emphasized in functional, efficiency-based arguments about path dependence (e.g. Pierson, 2000).

8. Primary documents used in the study include minutes and reports of WHO meetings, archival files on the region-building process, documentation of WHAs and Executive Board meetings, DG speeches, and WHO publications and reports. In addition, I draw on secondary literature from the domains of public health, international law, and medical history, as well as oral histories published at the WHO archives.

9. Other regional bodies that existed at the time of the WHO's creation were a range of sanitary councils in colonized territories and the regional bureaus of the OIHP and the LNHO. Still, the question of their continued authority was never seriously raised (Goodman, 1971: 318-320; Howard-Jones, 1981: 17).

10. Initially hoping to preserve its regional sanitary board as the 'Pan Arab Regional Health Bureau,' Egypt was another strong supporter of regionalization (Howard-Jones, 1981: 17).

11. A range of states including Australia, New Zealand, Ireland, China, Canada, and the US tried to postpone this first step toward region-building until the WHO was firmly established, but they were outvoted (WHO, 1948a: 58, 270).

12. The '70-30' principle continues to serve as a benchmark in the WHO's budgeting process, although an aspirational one (see WHO, 2011b: 14).

13. Author's interviews with two WHO officers at headquarters, Geneva, 10 September and 22 September 2010.

14. Using Albert Hirschman's (1970) terminology, one may say that even powerful WHO 
reformers preferred less costly strategies such as voice and loyalty over all-out exit. I thank an anonymous reviewer for pointing out this connection. On exit and path-dependent IO change, see also Hanrieder (2014b).

\section{References}

Alter KJ (1998) Who are the 'masters of the treaty'? European governments and the European Court of Justice. International Organization 52(1): 121-147.

Andresen S (2002) Leadership change in the World Health Organization: Potential for increased effectiveness? FNI Report 8/2002, Lysaker.

Ascher CS (1952) Current problems in the World Health Organization's program. International Organization 6(2): 27-50.

Bachrach P and Baratz MS (1962) Two faces of power. American Political Science Review 56(4): 947-952.

Barnes B (2001) Practice as collective action. In: Schatzki TR, Knorr Cetina K and Von Savigny E (eds) The Practice Turn in Contemporary Theory. London and New York, NY: Routledge, $25-35$.

Barnett M and Duvall R (eds) (2005) Power in Global Governance. Cambridge: Cambridge University Press.

Barnett M and Finnemore M (2004) Rules for the World: International Organizations in Global Politics. Ithaca, NY: Cornell University Press.

Beigbeder Y (1997) The Internal Management of United Nations Organizations: The Long Quest for Reform. New York, NY: St. Martin's Press.

Brundtland GH (1998) Address to permanent missions in Geneva. WHO, Headquarters, Geneva (18 November). Available at: http://www.who.int/director-general/speeches/1998/english/19981110_missions.html (accessed 11 August 2011).

Brundtland GH (1999) Address to the Geneva Group - UN directors. Change at WHO. Geneva (2 March). Available at: http://www.who.int/director-general/speeches/1999/english/19990302_un_directors.html (accessed 16 August 2011).

Calderwood HB (1963) The World Health Organization and its regional organizations. Temple Law Quarterly 37(1): 15-27.

Capoccia G and Kelemen RD (2007) The study of critical junctures: Theory, narrative, and counterfactuals in historical institutionalism. World Politics 59(3): 341-369.

Chorev N (2012) The World Health Organization between North and South. Ithaca, NY: Cornell University Press.

Chow JC (2010) Is the WHO becoming irrelevant? Why the world's premier public health organization must change or die. Foreign Policy, 8 December. Available at: http:/www.foreignpolicy.com/articles/2010/12/08/is_the_who_becoming_irrelevant (accessed 30 March 2011).

Cueto M (2004) The origins of primary health care and selective primary health care. American Journal of Public Health 94(11): 1864-1874.

Daes E-I and Daoudy A (1993) Decentralization of the Organizations within the United Nations System, Part III: The World Health Organization. JIU/REP/93/2. Geneva: United Nations Joint Inspection Unit.

Danida (1991) Effectiveness of multilateral agencies at country level: WHO in Kenya, Nepal, Sudan and Thailand. Prepared for Danida by COWIconsult, Copenhagen.

Dannreuther R (2011) Understanding the Middle East peace process: A historical institutionalist approach. European Journal of International Relations 17(2): 187-208.

Drezner DW (2010) Is historical institutionalism bunk? Review of International Political Economy 17(4): 791-804. 
FAO (Food and Agriculture Organization of the United Nations) (2007) FAO: The Challenge of Renewal. Report of the Independent External Evaluation of the Food and Agriculture Organization of the United Nations (FAO). Rome: Food and Agriculture Organization of the United Nations.

Farley J (2008) Brock Chisholm, the World Health Organization, and the Cold War. Vancouver, Toronto: UBC Press.

Fearon JD (1998) Bargaining, enforcement, and international cooperation. International Organization 52(2): 269-305.

Fioretos O (2011) Historical institutionalism in International Relations. International Organization 65(2): 367-399.

Galanter M (1974) Why the 'haves' come out ahead: Speculations on the limits of legal change. Law \& Society Review 9(1): 95-160.

Godlee F (1994) The regions: Too much power, too little effect. British Medical Journal 309(6968): $1566-1570$.

Godlee F (1995) Interview with the director general. British Medical Journal 310(6979): 583-588.

Godlee F (1998) Change at last in WHO: But will the regions play ball? British Medical Journal 317(7154): 296-300.

Goodman NM (1971) International Health Organizations and Their Work. Philadelphia, PA: Churchill Livingstone.

Graham E (2013) International organizations as collective agents: Fragmentation and the limits of principal control at the World Health Organization. European Journal of International Relations. Epub ahead of print, 30 May. DOI: 10.1177/1354066113476116.

Gruber L (2000) Ruling the World. Power Politics and the Rise of Supranational Institutions. Princeton, NJ: Princeton University Press.

Hall PA and Taylor RC (1996) Political science and the three new institutionalisms. Political Studies 44(5): 936-957.

Hanrieder T (2013) Local orders in international organizations: The World Health Organization's global programme on AIDS. Journal of International Relations and Development online first: 19 April.

Hanrieder T (2014a) WHO orchestrates? Coping with competitors in global health. In: Abbott KW, Genschel P, Snidal D et al. (eds) International Organizations as Orchestrators. Cambridge: Cambridge University Press.

Hanrieder T (2014b) Gradual change in international organizations: Agency theory and historical institutionalism. Politics online first: 12 February.

Henderson DA (2009) Smallpox: The Death of a Disease. Amherst, NY: Prometheus Books.

Hirschman AO (1970) Exit, Voice and Loyalty: Responses to Decline in Firms, Organizations, and States. Cambridge, MA: Harvard University Press.

Horton R (2013) A renaissance in WHO's regions. The Lancet 383(9904): 1544.

Howard-Jones N (1978) International Public Health Between the Two World Wars - The Organizational Problems. Geneva: World Health Organization.

Howard-Jones N (1981) The Pan American Health Organization: Origins and Evolution. Geneva: World Health Organization.

Hull C (1948) The Memoirs. New York, NY: Macmillan.

Jacobson HK (1973) WHO: Medicine, regionalism, and managed politics. In: Cox RW and Jacobson HK (eds) The Anatomy of Influence. Decision Making in International Organizations. New Haven, CT: Yale University Press, 175-215.

Joint Inspection Unit (2001) Review of Management and Administration in the World Health Organization (WHO). JIU/REP/2001/5. Geneva: Joint Inspection Unit of the UN System. 
Jupille JH, Mattli W and Snidal D (2013) Institutional Choice and Global Commerce. Cambridge and New York, NY: Cambridge University Press.

Keohane RO (1984) After Hegemony: Cooperation and Discord in the World Political Economy. Princeton, NJ: Princeton University Press.

Kleine M (2013) Trading control: National fiefdoms in international organizations. International Theory 5(3): 321-346.

Knight J (1992) Institutions and Social Conflict. Cambridge: Cambridge University Press.

Koremenos B, Lipson C and Snidal D (2001a) The rational design of international institutions. International Organization 55(4): 761-799.

Koremenos B, Lipson C and Snidal D (2001b) Rational design: Looking back to move forward. International Organization 55(4): 1051-1082.

Krasner SD (1984) Approaches to the state: Alternative conceptions and historical dynamics. Comparative Politics 16(2): 223-246.

Krasner SD (1991) Global communications and national power: Life on the Pareto frontier. World Politics 43(3): 336-366.

Lee K (2009) World Health Organization. London: Routledge.

Lerer L and Matzopoulos R (2001) 'The worst of both worlds': The management reform of the World Health Organization. International Journal of Health Service 31(2): 415-438.

Levine R (2006) Open letter to the incoming director-general of the World Health Organization: Time to refocus. British Medical Journal 333(7576): 1015-1017.

Levy G (1982) Transcript of an Oral Interview with Professor Milton P. Siegel Moderated by Mr Gino Levy With the Participation of Mr Norman Howard-Jones. Geneva, 15 and 19 November. Geneva: World Health Organization.

Litsios S (2002) The long and difficult road to Alma Ata: A personal reflection. International Journal of Health Services 32(4): 709-732.

Mahler H (1975) New possibilities for WHO. WHO Chronicle 29(2): 43-45.

Mahler H (1980) The WHO you want: An address to WHO regional committees. WHO Chronicle 34(1): 3-8.

Mahler H (1981) The meaning of 'Health for all by the year 2000.' World Health Forum 2(1): $5-22$.

Mahler H (1983a) The marathon for health for all. WHO Chronicle 37(6): 187-191.

Mahler H (1983b) WHO's programme budget since 1980: Some lessons for the 1984-85 biennium. WHO Chronicle 37(2): 43-47.

Mahler H (1984) Voices in harmony for health for all. WHO Chronicle 38(4): 155-160.

Mahoney J (2000) Path dependence in historical sociology. Theory and Society 29(4): 507-548.

Mahoney J and Thelen K (2010) A theory of gradual institutional change. In: Mahoney J and Thelen K (eds) Explaining Institutional Change: Ambiguity, Agency, and Power. Cambridge: Cambridge University Press, 1-37.

Martin LL (1992) Interests, power, and multilateralism. International Organization 46(4): 765-792.

Moe TM (1990) Political institutions: The neglected side of the story. Journal of Law, Economics, and Organization 6(special issue): 213-253.

Moe TM (2005) Power and political institutions. Perspectives on Politics 3(2): 215-233.

Newell KW (ed.) (1975) Health by the People. Geneva: World Health Organization.

Nielson DL, Tierney MJ and Weaver CE (2006) Bridging the rationalist-constructivist divide: Re-engineering the culture of the World Bank. Journal of International Relations and Development 9(2): 107-139.

Page SE (2006) Path dependence. Quarterly Journal of Political Science 1(1): 87-115.

Peabody JW (1995) An organizational analysis of the World Health Organization: Narrowing the gap between promise and performance. Social Science and Medicine 40(6): 731-742. 
Pierson P (1996) The path to European integration: A historical institutionalist perspective. Comparative Political Studies 29(2): 123-163.

Pierson P (2000) Increasing returns, path dependence, and the study of politics. American Political Science Review 94(2): 251-267.

Pierson P (2004) Politics in Time: History, Institutions, and Social Analysis. Princeton, NJ, and Oxford: Princeton University Press.

Posta I and Zahran MM (2012) Review of Management, Administration and Decentralization in the World Health Organization. Part II Review of Decentralization in WHO. Geneva: United Nations Joint Inspection Unit.

Robbins A (1999) Brundtland's World Health Organization. A test case for United Nations management reform. Public Health Reports 114(1): 30-39.

Roll Back Malaria and World Health Organization (2002) Achieving impact: Roll Back Malaria in the next phase: Final report of the external evaluation of Roll Back Malaria. Available at: http://www.rollbackmalaria.org/cmc_upload/0/000/015/905/ee_toc.htm (accessed 28 October 2010).

Roman-Morey E and Zahran MM (2011) Review of Management and Administration in the United Nations Educational, Scientific, and Cultural Organization (UNESCO). Geneva: United Nations Joint Inspection Unit.

Scharpf FW (1988) The joint-decision trap: Lessons from German federalism and European integration. Public Administration 66(3): 139-278.

Sharp WR (1947) The new World Health Organization. American Journal of International Law 41(3): 509-530.

Siddiqi J (1995) World Health and World Politics: The World Health Organization and the UN System. London: Hurst \& Company.

Smith R (1995) The WHO: Change or die. British Medical Journal 310(6979): 543-544.

Soper FL (1977) Ventures in World Health: The Memoirs of Fred Lowe Soper (ed. John Duffy). Washington, DC: Pan American Health Organization.

Sridhar D and Gostin LO (2011) Reforming the World Health Organization. JAMA: The Journal of the American Medical Association 305(15): 1585-1586.

Staples ALS (2006) The Birth of Development: How the World Bank, Food and Agriculture Organization, and World Health Organization Changed the World, 1945-1965. Kent, OH: The Kent State University Press.

Stone RW (2009) Institutions, power, and interdependence. In: Milner HV and Moravcsik A (eds) Power, Interdependence, and Nonstate Actors in World Politics. Princeton, NJ, and Oxford: Princeton University Press, 31-49.

Strange S (1998) Why international organizations never die. In: Reinalda B and Verbeek B (eds) Autonomous Policy Making by International Organizations. London and New York, NY: Routledge, 213-220.

Thelen K (1999) Historical institutionalism in comparative politics. Annual Review of Political Science 2: 369-404.

Thelen K (2004) How Institutions Evolve: The Political Economy of Skills in Germany, Britain, the United States, and Japan. Cambridge, MA: Cambridge University Press.

Weaver CE (2008) Hypocrisy Trap: The World Bank and the Poverty of Reform. Princeton, NJ: Princeton University Press.

Wendt A (2001) Driving with the rearview mirror: On the rational science of institutional design. International Organization 55(4): 1019-1049.

WHO (World Health Organization) (1947a) Minutes of the Technical Preparatory Committee for the International Health Conference. Official Records of the World Health Organization 1. Geneva and New York, NY: World Health Organization, Interim Commission. 
WHO (1947b) Minutes of the second session of the Interim Commission. Official Records of the World Health Organization 4. Geneva and New York, NY: World Health Organization, Interim Commission.

WHO (1948a) First World Health Assembly. Official Records of the World Health Organization 13. Geneva: World Health Organization.

WHO (1948b) Reports of the Executive Board first and second sessions. Official Records of the World Health Organization 14. Geneva: World Health Organization.

WHO (1949) Second World Health Assembly. Official Records of the World Health Organization 21. Geneva: World Health Organization.

WHO (1953) Executive Board. Eleventh session. Official Records of the World Health Organization 46. Geneva: World Health Organization.

WHO (1956) Executive Board. Nineteenth session. 15-30 January 1957. Part I resolutions annexes. Official Records of the World Health Organization 76. Geneva: World Health Organization.

WHO (1958a) Executive Board. Twenty-second session. 16 and 17 June 1958. Resolutions annexes. Official Records of the World Health Organization 88. Geneva: World Health Organization.

WHO (1958b) Executive Board. Twenty-Second Session. Minutes of the Second Meeting. EB22/ Min/2 Rev.1. Geneva: World Health Organization.

WHO (1959a) Executive Board. Twenty-Third Session. Minutes of the Eleventh Meeting. Geneva: World Health Organization.

WHO (1959b) Executive Board. Twenty-Third Session. Provisional Agenda Item 8.12: Method of Appointing Regional Directors. Proposal submitted by Dr Metcalfe. EB23/79. Geneva: World Health Organization.

WHO (1964) Procedure for the Nomination of Regional Directors. Report by the Director-General. Annex 19 to Executive Board, thirty-third session. 14-24 January 1964. Part I resolutions annexes, 89-93. OR132/Annex19. Geneva: World Health Organization.

WHO (1976) Report of the Programme Committee of the Executive Board. EB59/6. Geneva: World Health Organization.

WHO (1979) Study of WHO's Structures in the Light of its Functions: WHO's Processes, Structures, and Working Relationships. Director-General's Report. EB65/18. Geneva: World Health Organization.

WHO (1980) The WHO You Deserve. Address by Dr H. Mahler Director-General of the World Health Organization in Presenting his Report for 1978 and 1979 to the Thirty-Third World Health Assembly. WHA33/DIV/4. Geneva: World Health Organization.

WHO (1984) Proposed Programme Budget for the Financial Period 1986-1987. PB/86-87. Geneva: World Health Organization.

WHO (1986) Proposed Programme Budget for the Financial Period 1988-1989. PB/88-89. Geneva: World Health Organization.

WHO (1987a) Executive Board: Provisional Summary Records of the Twenty-First Meeting. EB79/SR21. Geneva: World Health Organization.

WHO (1987b) Management of WHO's Resources. EB81/PC/WP/2. Geneva: World Health Organization.

WHO (1987c) World Health for All: To Be! Address by Dr H. Mahler, Director-General of the World Health Organization in Presenting his Report for 1986 to the Fortieth World Health Assembly. WHA40/DIV/4. Geneva: World Health Organization.

WHO (1999) The World Health Report 1999: Making a Difference. Geneva: World Health Organization.

WHO (2008) The Third Ten Years of the World Health Organization: 1968-1977. Geneva: World Health Organization. 
WHO (2011a) The Fourth Ten Years of the World Health Organization: 1978-1987. Geneva: World Health Organization.

WHO (2011b) Programme Budget 2012-2013. Geneva: World Health Organization.

Yamey G (2002a) Have the latest reforms reversed WHO's decline? British Medical Journal 325(7372): 1107-1112.

Yamey G (2002b) WHO's management: Struggling to transform a 'fossilized bureaucracy.' British Medical Journal 325(7373): 1170-1173.

Yamey G and Abbasi K (2003) New leader, new hope for WHO: Setting an agenda for Jong-Wook Lee. British Medical Journal 326(7399): 1251-1252.

Zacher MW and Keefe TJ (2008) The Politics of Global Health Governance: United by Contagion. New York, NY, and Basingstoke: Palgrave Macmillan.

\section{Author biography}

Tine Hanrieder is an Assistant Professor at LMU Munich, Germany. She researches international organizations, global health politics, and normative discourse in world politics. Her work is published in scholarly journals including International Theory, Security Dialogue, and the Journal of International Relations and Development. 